\title{
Imprime PGG, a yeast $\beta$-glucan immunomodulator, has the potential to repolarize human monocyte- derived M2 macrophages to M1 phenotype
}

\author{
Anissa SH Chan, Xiaohong Qiu, Adria Bykowski Jonas, Myra L Patchen, Nandita Bose* \\ From Society for Immunotherapy of Cancer 29th Annual Meeting \\ National Harbor, MD, USA. 6-9 November 2014
}

\section{Background and objective}

Imprime PGG (IPGG) has shown promising clinical efficacy in combination with monoclonal antibody treatment of cancer [1]. In mice, complement receptor 3 (CR3) on innate immune cells (neutrophils and macrophages) is required for IPGG's anti-tumor activity $[2,3]$. In human in vitro studies, opsonized IPGG binds CR3 on neutrophils and monocytes, but only on cells from individuals with high levels of endogenous anti- $\beta$-glucan antibodies (ABA), which is also a potential biomarker for enhanced clinical response to IPGG [1]. Although IPGG has been shown to prime circulating neutrophils and monocytes, no data is available on its effect on N1/ N2 neutrophil or M1/M2 macrophage tissue counterparts that can skew the immunostimulatory $v s$. immunosuppressive balance of the tumor microenvironment. The objective of this study was to investigate effects of IPGG treatment on monocyte differentiation to M1 or M2 macrophages.

\section{Design and results}

Monocytes enriched from IPGG- or vehicle-treated whole blood were cultured for six days in media containing GM-CSF or M-CSF to induce differentiation to M1 or M2 macrophages, respectively. Cells were then evaluated phenotypically for a panel of markers (including HLA-DR, CD163, CD206, CD209, CD80, CD86 and PD-L1) and functionally for the ability to drive CD4 Tcell proliferation and Th1 polarization. IPGG pretreatment did not affect M1 but did affect M2 as evidenced by down-modulation of CD163 and the ability of the cells to enhance $\mathrm{CD} 4 \mathrm{~T}$ cell proliferation with a concomitant increase in interferon gamma production

Biothera, Eagan, MN, USA Attribution License (http://creativecommons.org/licenses/by/4.0), which permits unrestricted use, distribution, and reproduction in any medium, provided the original work is properly cited. The Creative Commons Public Domain Dedication waiver (http:// creativecommons.org/publicdomain/zero/1.0//) applies to the data made available in this article, unless otherwise stated. 


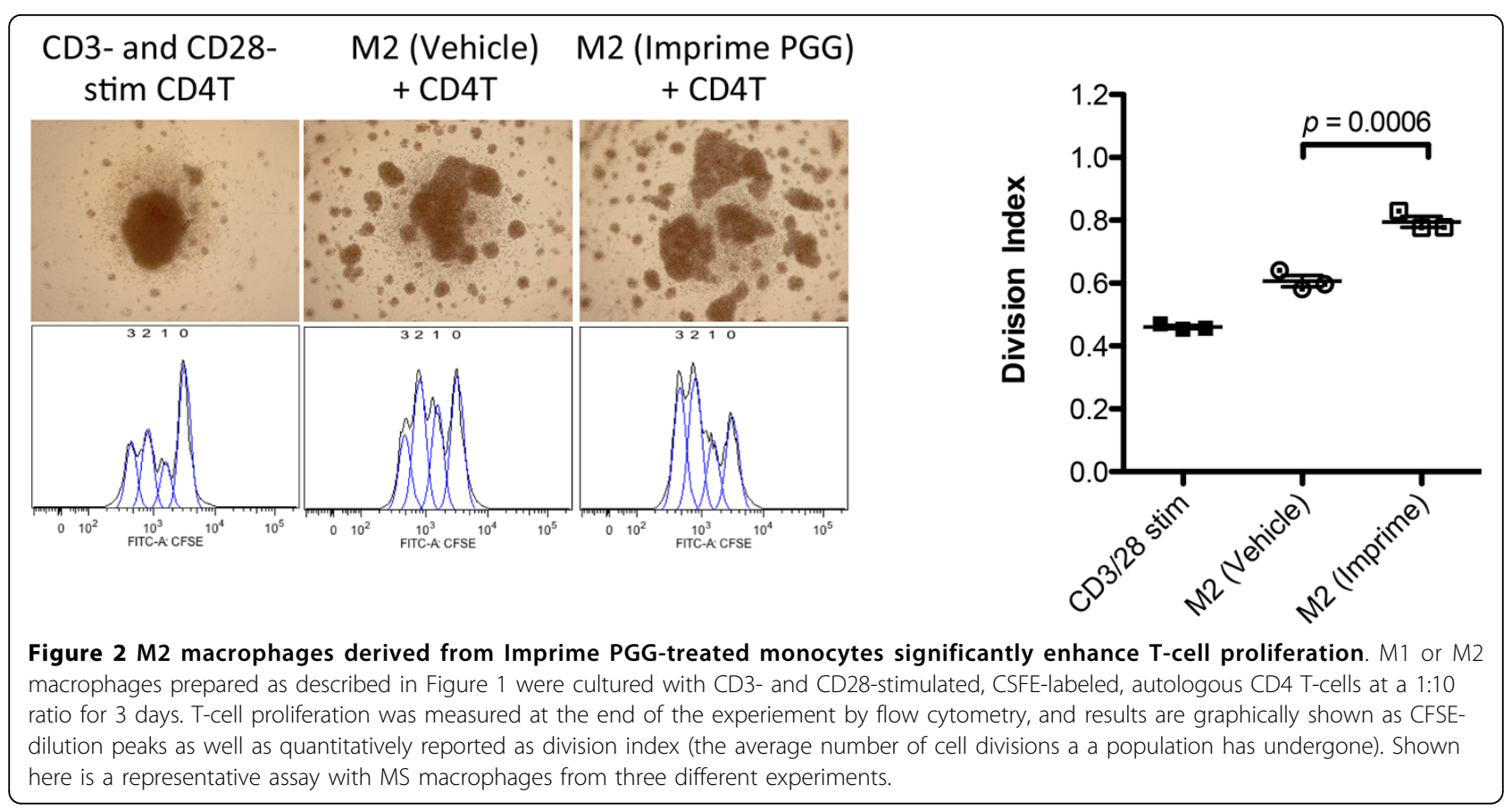

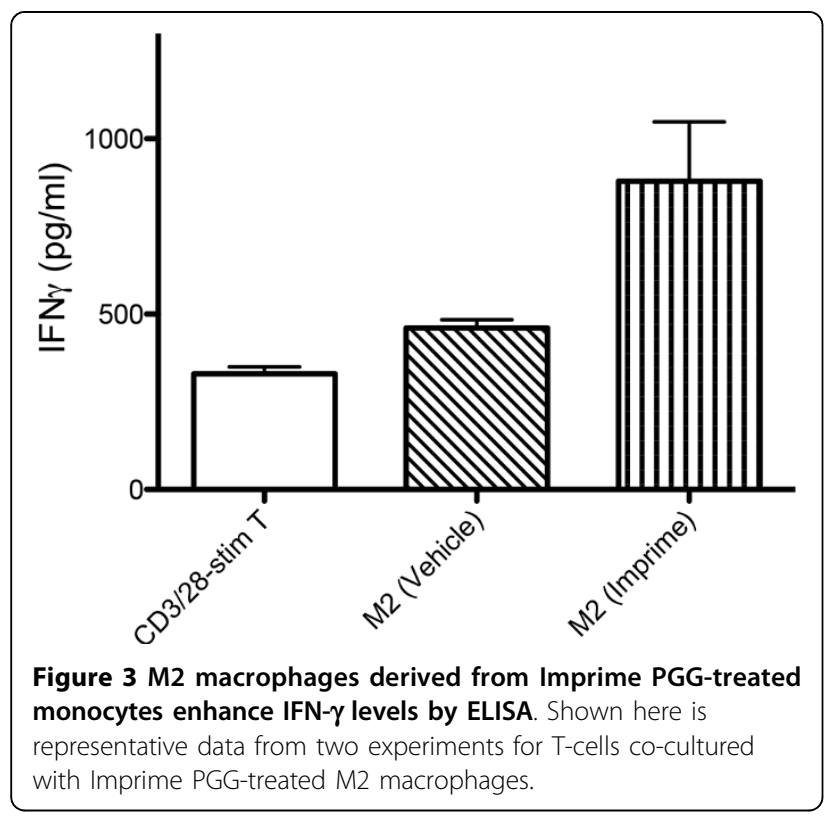

(Figures 1,2,3). These changes were only observed in cells of individuals with high ABA levels.

\section{Conclusions}

IPGG has the potential to affect M2 to M1 repolarization and drive Th1 polarization. This engagement of the adaptive, along with the innate, immune system suggests that exploration of IPGG in combination with immunosuppression-relieving anti-cancer agents is warranted.
Published: 6 November 2014

\section{References}

1. Bose $N$, Antonysamy MA, Patchen ML, et al: Endogenous anti- $\beta$-glucan antibodies as a potential predictive biomarker for clinical response to Imprime PGG immunotherapy in non-small cell lung cancer (NSCSL) patients. J Clin Oncol 2014, 32:5s, (suppl; abstr 3045).

2. Li B, Allendorf $D$, Hansen $R$, et al: Yeast beta-glucan amplifies phagocyte killing of iC3b-opsonized tumor cells via complement receptor 3-Sykphosphatidylinositol 3-kinase pathway. J Immunol 2006, 177:1661-1669.

3. Qi C, Cai Y, Gunn L, et al: Differential pathways regulating innate and adaptive antitumor immune responses by particulate and soluble yeastderived $\beta$-glucans. Blood 2011, 117:6825-6836.

\section{doi:10.1186/2051-1426-2-S3-P191}

Cite this article as: Chan et al:: Imprime PGG, a yeast $\beta$-glucan immunomodulator, has the potential to repolarize human monocytederived M2 macrophages to M1 phenotype. Journal for ImmunoTherapy of Cancer 2014 2(Suppl 3):P191.

\section{Submit your next manuscript to BioMed Central} and take full advantage of:

- Convenient online submission

- Thorough peer review

- No space constraints or color figure charges

- Immediate publication on acceptance

- Inclusion in PubMed, CAS, Scopus and Google Scholar

- Research which is freely available for redistribution 